TURIZAM

Volume 23, Issue 2

$69-85$ (2019)

ORIGINAL

SCIENTIFIC PAPER

\section{Labor Force Analysis in Food and Beverage Establishments in Kyrgyzstan: A Descriptive Study}

\author{
Barış Erdem ${ }^{A}$, Gülmira Samatova ${ }^{B}$, Nadira Turganbayeva ${ }^{B}$, \\ Sapargül Turdubekova ${ }^{B}$, Dinara İsakova ${ }^{B}$ \\ Received: February 2019 | Accepted: Jun 2019 \\ DOI: 10.5937/turizam23-20686
}

\begin{abstract}
In this research were aimed to determine the profiles of employees working at food and beverage establishments in Kyrgyzstan. Data of the research are collected by survey technique from 304 employees who work in different positions of 21 food and beverage establishments in Bishkek. According to findings; more than half of the employees are female and single, a majority of them are between 17 and 30 years old and more than 50\% of the participants are vocational school or bachelor graduates. In addition to these findings, the results indicate that around one of every two participants have no tourism education at any level. It is revealed that almost half of the participants work from 9 to 12 hours and average wage of most of these employees is under 250 dollars per month. Nevertheless, it was detected that almost half of the participants were generally pleased to work in food and beverage sector.
\end{abstract}

Keywords: Food and Beverage Establishments, Human Resources, Kyrgyzstan.

\title{
Introduction
}

As the tourism industry which has quite a complex structure is split into sub sectors, it is sometimes quite hard to classify areas of activity included under that industry (Erdem, 2010: 118). Baker et al. (1998: 3 ) classifies the products and services included under tourism as follows:

- transportation businesses (i.e. rent a car companies, travel agencies and tour operators);

- $\quad$ food and beverage establishments (i.e. restaurants, bars, cafeterias);

- $\quad$ accommodation establishments (i.e. hotels, guest houses, holiday villages);

- recreation facilities (i.e. theme parks, aqua parks);

- other ancillary service businesses (i.e. souvenir shops).

A University of Balıkesir, Faculty of Tourism, Department of Recreation Management, Çağış Campus, Balıkesir, Turkey \& University of Kyrgyz-Turkish Manas, The School of Tourism and Hotel Management, Department of Tourism and Hotel Management, 56 Chyngyz Aitmatov Avenue, Bishkek, Kyrgyzstan; Corresponding author: berdem2110@gmail.com

B University of Kyrgyz-Turkish Manas, The School of Tourism and Hotel Management, Department of Gastronomy and Culinary Arts, 56 Chyngyz Aitmatov Avenue, Bishkek, Kyrgyzstan 
As seen from this classification also, one of the elements contained within the scope of tourism industry are the food and beverage establishments. Pfitzer and Krishnaswamy (2007:6) state that "as being crucial for human life and health all around the world, food \& beverage industry has a key role to prompt the economic opportunity". Food and beverage establishments can be defined as "the commercial enterprises that meets eating-drinking needs of people" in the simplest way (Akın, Akın, 2013: 1). In Turkey in Article 26 of Regulations For Certification and Qualities of Tourism Facilities, the definition with respect to eating and drinking facilities was given as restaurant. According to that, restaurants are defined as "the facilities that meet eating-drinking needs with fixed menu, a la carte or special meal and services suitable to those meals" (internet 1).

Some authors predicate the development in food and beverage industry on the influences of industrial revolution. Accordingly, it is asserted that the rate of eating outside has started to grow due to factors after the industrial revolution such as the increase of women's role in business life, the extension of business hours in general and the raise in welfare level of people (Kılıç, Eleren, 2009: 93 cited by Olcay, Özekici, 2015: 1254). In this context, it is told that the first known form of food and beverage establishments in historical process are the coffee houses and that the first coffee entrepreneurship were first met in England during the mid 16oos. But it is stated that the first food and beverage establishment was opened in Paris in the year 1765 (Doğdubay, Karan, 2015: 25).

Besides, it is expressed that the demand towards food and beverage establishment at the present time which grows each passing day, leads to an intense competition experienced between such establishments (Güler, 2007: 101). Likewise, Chan et al. (2014) also state that food services industry is growing rapidly in the global market. In this context, the authors assert that the entrepreneurship in the field of food and beverage establishment has increased in business world in order to get more share from economic acquisitions created by the said industry, and as a consequence, that a fierce competition has occurred between food and beverage establishments. In a manner to support the said cases, some authors describe food and beverage industry as a quite tough and competitive sector and state that the executives should bear more responsibilities in this high risk industry (Koşan, 2013: 203).

According to Koşan (2013: 217), strategic decisions taken by the administration in order to shape the future of the organization in establishments providing food and beverage service are very important as in all other establishments too. One of these strategic decisions may be associated with human resources.

Thus, the importance attached to information and intellectual capital in recent years have made human the most important production factor. In this context, it is witnessed that today's organizations show more efforts than ever to attract qualified employees and keep them within (Yelboğa, 2008: 12). Likewise, Sabuncuoğlu (2000) also asserts that the most important element to steer a company and lead them to success or failure is the man power.

At the present time, the most critical factors for organizations related to human resources are to recruit, train, energize and motivate talented employees and be able to employ them for a long time. However, despite many organizations are aware of the importance of having talented labor force to stay competitive, a challenging effort is required to attract such employees towards the establishment and keep them within (Doğan, Demiral, 2008: 152).

Although labor force is considered to be the main element for active establishments in all sectors, it has a particular importance in terms of tourism establishments. "Tourism and hospitality industries are creating many job opportunities for millions of people worldwide in different areas such as food and beverage, accommodation, airports, airlines, aircrafts, cruis- 
es, ships, boats, land transportations i.e. trail, bus; tour operation companies, travel agencies, natural and cultural attractions i.e. monuments, caves, museums and galleries, national parks, concerts, festivals, theatres, carnivals, conferences, exhibitions and trade show" (Aynalem et al., 2016: 4). Aynalem et al. (2016: 1) suggest that "in tourism and hospitality sectors, the staff is the heart for prompt and excellent service delivery system”. Similarly, according to Kuşluvan et al. (2010: 171), "for tourism and hospitality establishments, one of the most important key points is regarded as the human resources". Also, Baum et al. (2016: 1) suggest that "although the technology and its substitution has largely replaced the labor within the workplace, tourism organizations still depend on labour-intensive work done by their personnel". The labor-intensive characteristics of tourism industry makes labor force a strategic element for establishments active in this sector. In this context, labor force in tourism establishments is considered to be one of the most important source in reaching organizational effectiveness (İçöz, 1991; Mullins, 1995; Akoğlan, Kozak, 1995; Saldaml,, 2000; Erdem, 2003; Akçadağ, Özdemir, 2005; Usal, Kurgun, 2006; Nickson, 2007; Swain, George, 2007; Gruescu et al., 2008; Kusluvan et al., 2010; Milić et al., 2011; Bhutia, 2014; Erdem, Gezen, 2014; Baum, 2015; Erdem et al., 2015; Herman, 2015; Prayag, Hosany, 2015; Erdem, 2016; Baum et al., 2016; Ganie, Dar, 2018; Hady, Chible, 2018, Erdem, 2019).

Besides, it is stated in some researches in the literature that operations conducted in food and beverage establishments are based on labor force (Doğdubay, Karan, 2015: 25). Accordingly, it can be said that employees are of critical importance for food and beverage establishments to stay competitive. In this context, Crick \& Spencer (2011: 469 adapted from internet 2) state that "in food and beverage service, it is observed that employee performance is a critical point in maintaining the quality". However, Friddle et al. (2001) point out that the biggest problem for foodservice industry is the labor shortage.

In this research, it was intended to reveal profiles of labor force that are employed at food and beverage establishments in Kyrgyzistan. For this purpose, it was attempted to determine demographic features of employees, whether or not they had tourism education, their experiences in food and beverage industry, their levels of foreign language and pleasure to work in the food and beverage sector.

In the relevant literature, studies focused on labor force profile at tourism establishments in Kyrgyzstan are quite limited. Studies in the literature are generally focused on labor force profile at accommodation enterprises. In this context, two studies were found related with this subject. In one of those studies (Erdem et al., 2015), profiles of employees working at accommodation facilities active in the capital of Kyrgyzstan, Bishkek; and in the second one (Erdem et al., 2016), the profiles of ones working at Issyk-Kul Lake and Osh regions of Kyrgyzstan were revealed.

At least no study was found within the knowledge of researchers aiming to determine the profiles of employees working at food and beverage establishments in Kyrgyzstan. Accordingly, findings obtained from this research are expected to contribute to the relevant literature. 


\section{Overall View to Food and Beverage Sector in Kyrgyzstan}

According to year 2018 data of National Statistical Committee of the Kyrgyz Republic, distribution of the registered tourism establishments according to their types which are active in tourism sector in the country is given in Table 1.

Table 1. The Types of Tourism Establishments in Kyrgyzstan

\begin{tabular}{|l|c|c|c|c|c|}
\hline Types of Enterprises & 2013 & 2014 & 2015 & 2016 & 2017 \\
\hline Hotels & 142 & 146 & 157 & 168 & 181 \\
\hline Tourism Enterprises and Resting Facilities & 202 & 210 & 224 & 230 & 244 \\
\hline Restaurants & 380 & 393 & 411 & 424 & 457 \\
\hline Travel Agencies & 2049 & 2172 & 2274 & 2402 & 2499 \\
\hline Sanatorium and Kurort & 74 & 75 & 73 & 75 & 78 \\
\hline Nature Protection Areas and National Parks & 19 & 19 & 19 & 19 & 22 \\
\hline TOTAL & 2866 & 3015 & 3158 & 3318 & 3481 \\
\hline
\end{tabular}

Source: internet 3

As seen also in Table 1, the area that dominates tourism sector in Kyrgyzstan is travel agencies. As of the year 2017, total number of travel agencies is 2499. This is followed by restaurants, tourism enterprises and resting facilities and hotels. Establishments which are included in the category of tourism enterprises and resting facilities refer to accommodation enterprises other than hotel establishments (holiday villages, lodgings, guest houses, camps etc.).

On the other side, only the number of restaurants can be found in these data of National Statistical Committee of the Kyrgyz Republic for food and beverage enterprises. In the said data, no information is available for other food and beverage enterprises other than restaurants. As seen also in Table 1, the number of registered restaurants in Kyrgyzstan as of the year 2017 is 457. Among these 457 restaurants, 399 are active in Bishkek (internet 3).

On the other side, the data in Table 2 is given related to number of employees working at tourism establishments in Kyrgyzstan.

Table 2. Average Number of People Working at Tourism Establishments in Kyrgyzstan

\begin{tabular}{|l|c|c|c|c|c|}
\hline Types of Enterprises & $\mathbf{2 0 1 3}$ & $\mathbf{2 0 1 4}$ & $\mathbf{2 0 1 5}$ & $\mathbf{2 0 1 6}$ & $\mathbf{2 0 1 7}$ \\
\hline Hotels & 1643 & 1693 & 1641 & 1512 & 1235 \\
\hline Tourism Enterprises and Resting Facilities & 1101 & 1164 & 1093 & 1518 & 1507 \\
\hline Restaurants & $\mathbf{8 3 6}$ & 1194 & 1072 & 1072 & 1216 \\
\hline Travel Agencies & 1418 & 1324 & 1454 & 1474 & 1574 \\
\hline Sanatorium and Kurort & 2458 & 2512 & 2526 & 2020 & 2298 \\
\hline Nature Protection Areas and National Parks & 681 & 666 & 659 & 688 & 644 \\
\hline TOTAL & $\mathbf{8 1 3 7}$ & $\mathbf{8 5 5 3}$ & $\mathbf{8 4 4 4}$ & $\mathbf{8 2 8 4}$ & $\mathbf{8 4 7 4}$ \\
\hline
\end{tabular}

Source: internet 3

As seen also in Table 2, 1216 registered people are working at the restaurants in Kyrgyzstan as of the year 2017 .

On the other hand, monthly average wages of the employees working at tourism establishments in Kyrgyzstan are given in data of Table 3. 
Table 3. Monthly Average Wages of Employees Working at Tourism Establishments in Kyrgyzstan (Som)

\begin{tabular}{|l|c|c|c|c|c|}
\hline Types of Enterprises & 2013 & 2014 & 2015 & 2016 & 2017 \\
\hline Hotels & 12914 & 12632 & 13557 & 15300 & 17485 \\
\hline Tourism Enterprises and Resting Facilities & 5602 & 6000 & 6829 & 7722 & 9211 \\
\hline Restaurants & 5148 & 6085 & 6211 & 6691 & 6531 \\
\hline Travel Agencies & 6432 & 6784 & 7836 & 7684 & 8278 \\
\hline Sanatorium and Kurort & 8780 & 9306 & 8771 & 9325 & 9784 \\
\hline Nature Protection Areas and National Parks & 6419 & 7221 & 10064 & 11511 & 11599 \\
\hline
\end{tabular}

Source: internet 3

As seen also in Table 3, monthly average wages of employees working at the restaurants in Kyrgyzstan were recorded as 6531 Som as of the year 2017. In other words, it is understood that the labor in restaurants are working for a monthly wage of 100 American Dollars approximately.

Besides, number of the registered food and beverage enterprises and their regional distribution were also found in some data published by National Statistical Committee of the Kyrgyz Republic. Accordingly, the number of registered food and beverage enterprises in the country and their regional distribution are as given in Table 4.

Table 4. The Number of Food and Beverage Enterprises in Kyrgyzstan and Their Distribution by Region

\begin{tabular}{|l|c|c|c|c|c|}
\hline Regions & 2000 & 2003 & 2007 & 2011 & 2015 \\
\hline Batken & 214 & 224 & 348 & 421 & 409 \\
\hline Jalal-Abad & 570 & 464 & 595 & 622 & 724 \\
\hline Issyk-Kul Lake & 118 & 132 & 153 & 118 & 130 \\
\hline Naryn & 71 & 73 & 78 & 76 & 70 \\
\hline Osh & 444 & 591 & 806 & 126 & 759 \\
\hline Talas & 69 & 81 & 433 & 381 & 197 \\
\hline Chuy & 396 & 436 & 840 & 994 & 419 \\
\hline Bishkek City & 594 & 763 & 403 & 325 & 1016 \\
\hline Osh City & 408 & 434 & 3831 & 3815 & 396 \\
\hline TOTAL & 2884 & 3198 & & 4120 \\
\hline
\end{tabular}

Source: internet 4

As seen also in Table 4, the number of registered food and beverage enterprises in Kyrgyzstan as of the year 2015 is 4120 . Great majority of these enterprises are active in the capital Bishkek. This is followed by Osh, Jalal-Abad, Chuy and Batken regions. However, it is not clear which type of food and beverage enterprises that the said figures contain. Consequently, the above mentioned data had to be done with regarding the food and beverage enterprises in Kyrgyzstan. 


\section{Methodology}

\section{Purpose and Importance of the Research}

As eating outside is increasingly becoming popular nowadays, it leads a growth for entrepreneurship in food and beverage field and allows a big market formation in that field. Thus, food and beverage industry is accepted as one of the biggest sectors in the world due to its contributions to the economy (Akın, Akın, 2013: 1). In this context, some authors describe hospitality industry as the shining star of today's service industry and state that the first thing coming to mind when hospitality industry is mentioned is the food and beverage enterprises (Çekal, 2013: 63).

Besides, the rapid growth of food and beverage industry worldwide has increased the competition between the enterprises active in this industry. Although the food and beverage enterprises try different strategies in order to stay competitive in the said environment, the importance of having qualified employees in such enterprises still continue to be relevant. However, the researches conducted in order to determine profiles of employees working at food and beverage establishments are quite limited in the relevant literature. Particularly, there is a lack of information on general profile of labor force working at service industry in developing countries. In this research which is conducted based on that point, profiles of employees working at food and beverage enterprises active in Kyrgyzstan were tried to be found out. The findings obtained from the study are partially expected to fill the gap in the relevant field literature.

\section{Population and Sample}

Population of this study consists of employees working at food and beverage enterprises in Kyrgyzstan. For sample, the employees who are working at food and beverage enterprises active in Bishkek were selected. However, it was impossible to get information on the number of total employees working at such enterprises. In these data, it is mentioned that there are total of 399 registered restaurants active in Bishkek (internet 3). Except these 399 restaurants active in Bishkek, no other information was found for the number of any other types of food and beverage enterprises. In this context, by using convenience sampling method among non-probability sampling methods; 39 food and beverage enterprises in Bishkek were chosen, these enterprises were visited one by one and permission was requested from relevant executives to participate to the research. Positive response was taken from all the said 39 enterprises, however; data could be collected from 304 employees working at these enterprises (Table 5). Therefore, database of the research consisted of 304 employees working at food and beverage enterprises in Bishkek. 
Table 5: Food and Beverage Enterprises Participating to the Research

\begin{tabular}{|c|c|c|}
\hline Food and Beverage Enterprises & $\begin{array}{c}\text { Number of } \\
\text { Distributed } \\
\text { Questionnaires }\end{array}$ & $\begin{array}{c}\text { Number of } \\
\text { Collected } \\
\text { Questionnaires }\end{array}$ \\
\hline Enterprise 1 (Ala carte Restaurant) & 20 & 17 \\
\hline Enterprise 2 (Coffee Establishment) & 15 & 10 \\
\hline Enterprise 3 (Coffee Establishment) & 20 & 0 \\
\hline Enterprise 4 (Coffee Establishment) & 20 & 0 \\
\hline Enterprise 5 (Coffee Establishment) & 15 & 0 \\
\hline Enterprise 6 (Coffee Establishment) & 15 & 0 \\
\hline Enterprise 7 (Ala carte Restaurant) & 20 & 15 \\
\hline Enterprise 8 (Bar Establishment) & 20 & 0 \\
\hline Enterprise 9 (Coffee Establishment) & 20 & 0 \\
\hline Enterprise 10 (Coffee Establishment) & 20 & 0 \\
\hline Enterprise 11 (Coffee Establishment) & 15 & 15 \\
\hline Enterprise 12 (Coffee Establishment) & 20 & 13 \\
\hline Enterprise 13 (Coffee Establishment) & 20 & 0 \\
\hline Enterprise 14 (Ala carte Restaurant) & 15 & 13 \\
\hline Enterprise 15 (Coffee Establishment) & 15 & 15 \\
\hline Enterprise 16 (Ala carte Restaurant) & 25 & 15 \\
\hline Enterprise 17 (Coffee Establishment) & 15 & 10 \\
\hline Enterprise 18 (Ala carte Restaurant) & 20 & 20 \\
\hline Enterprise 19 (Bar Establishment) & 15 & 0 \\
\hline Enterprise 20 (Fast-Food Establishment) & 15 & 15 \\
\hline Enterprise 21 (Ala carte Restaurant) & 30 & 16 \\
\hline Enterprise 22 (Coffee Establishment) & 30 & 15 \\
\hline Enterprise 23 (Ala carte Restaurant) & 30 & 0 \\
\hline Enterprise 24 (Ala carte Restaurant) & 30 & 0 \\
\hline Enterprise 25 (Coffee Establishment) & 20 & 0 \\
\hline Enterprise 26 (Ala carte Restaurant) & 15 & 14 \\
\hline Enterprise 27 (Coffee Establishment) & 20 & 0 \\
\hline Enterprise 28 (Coffee Establishment) & 20 & 0 \\
\hline Enterprise 29 (Catering Establishment) & 30 & 17 \\
\hline Enterprise 30 (Coffee Establishment) & 5 & 0 \\
\hline Enterprise 31 (Coffee Establishment) & 15 & 0 \\
\hline Enterprise 32 (Coffee Establishment) & 20 & 0 \\
\hline Enterprise 33 (Coffee Establishment) & 20 & 0 \\
\hline Enterprise 34 (Ala carte Restaurant) & 20 & 14 \\
\hline Enterprise 35 (Catering Establishment) & 20 & 20 \\
\hline Enterprise 36 (Catering Establishment) & 20 & 15 \\
\hline Enterprise 37 (Catering Establishment) & 20 & 20 \\
\hline Enterprise 38 (Fast-Food Establishment) & 20 & 10 \\
\hline Enterprise 39 (Fast-Food Establishment) & 10 & 5 \\
\hline TOTAL & 755 & 304 \\
\hline
\end{tabular}




\section{Data Collection Instrument and Analysis}

Research data were collected by survey method. Questions included in questionnaire form were prepared by utilizing the studies of Erdem et al. (2015), and by considering the nationalities of the sample, the questionnaire form was copied in two languages (In Kyrgyz and Russian). The questionnaire was applied during June - September 2017 period by personally visiting the establishments. Some parts of the questionnaires were filled by talking to employees face to face, and some others were left to establishments and collected in later periods. However, some establishment directors stated that they were not able to make the employees fill in the questionnaire forms by showing work load as reason. In this manner, 304 questionnaires in number which were suitable to provide data could be obtained from 21 establishments. Frequency and percentage calculations were made on questionnaire data.

\section{Findings and Discussion}

In the research, demographic features of the group that constitute the sampling were examined. The results are given in Table 6.

Table 6. Demographic Features of the Participants

\begin{tabular}{|c|c|c|}
\hline Gender & Frequency (n) & Percentage (\%) \\
\hline Male & 128 & 42.1 \\
\hline Female & 169 & 55.6 \\
\hline No reply & 7 & 2.3 \\
\hline Age & Frequency (n) & Percentage (\%) \\
\hline $17-20$ & 98 & 32.2 \\
\hline $21-25$ & 124 & 40.8 \\
\hline $26-30$ & 44 & 14.5 \\
\hline $31-35$ & 15 & 4.9 \\
\hline $36-40$ & 11 & 3.6 \\
\hline $41-45$ & 5 & 1.6 \\
\hline $46-50$ & 3 & 1.0 \\
\hline 51 and above & 1 & 0.3 \\
\hline No reply & 3 & 1.0 \\
\hline Marital Status & Frequency (n) & Percentage (\%) \\
\hline Married & 92 & 30.3 \\
\hline Single & 195 & 64.1 \\
\hline Widow & 2 & 0.7 \\
\hline No reply & 15 & 4.9 \\
\hline Nationality & Frequency (n) & Percentage (\%) \\
\hline Kyrgyz & 274 & 90.1 \\
\hline Kazakh & 8 & 2.6 \\
\hline Uzbek & 1 & 0.3 \\
\hline Russian & 10 & 3.3 \\
\hline Turkish & 1 & 0.3 \\
\hline
\end{tabular}




\begin{tabular}{|l|c|c|}
\hline Other & 4 & 1.3 \\
\hline No reply & 6 & 2.0 \\
\hline Educational Status & Frequency (n) & Percentage (\%) \\
\hline Secondary School & 9 & 3.0 \\
\hline High School & 82 & 27.0 \\
\hline Vocational School & 92 & 30.3 \\
\hline Bachelor Degree & 90 & 29.6 \\
\hline Master's Degree & 4 & 1.3 \\
\hline No reply & 27 & 8.9 \\
\hline Did You Have Tourism Education? & Frequency (n) & Percentage (\%) \\
\hline Yes, at associate degree & 81 & 26.6 \\
\hline Yes, at bachelor degree & 36 & 11.8 \\
\hline Yes, I participated to tourism training courses & 30 & 9.9 \\
\hline No, I didn't have tourism education & 144 & 47.4 \\
\hline No reply & 13 & 4.2 \\
\hline Total & 304 & 100 \\
\hline
\end{tabular}

Based on the findings in Table 6, demographic features of the sampling can be summarized as follows: More than half of the participants $(55,6 \%)$ consist of female employees. In terms of age groups, the options standing out in the distribution are " $21-25$ " age range (40,8\%) and " $17-20$ " age range $(32,2 \%)$. Besides, it is remarkable that most of the employees are single $(64,1 \%)$. Predominance of Kyrgyz employees stands out among the participants $(\% 90,1)$. When we review the educational status of employees; we see that associate $(30,3 \%)$, bachelor $(29,6 \%)$ and high school (27\%) graduates stand out. However, it was identified that almost one of two participants $(47,4 \%)$ did not have a tourism education at any level. The ones stating that they had tourism education at associate level are at a rate of $26,6 \%$. And $11,8 \%$ of the sampling stated that they had tourism education at bachelor level. Based on these results, it comes to mind that there is a problem of labor force having vocational tourism education at food and beverage enterprises in Kyrgyzstan.

In the next stage, distribution of participants was reviewed according to their titles. The findings are given in Table 7.

Table 7. Distribution of Participants According to Their Titles

\begin{tabular}{|l|c|c|}
\hline Position & Frequency (n) & Percentage (\%) \\
\hline Waiter & 140 & 46.1 \\
\hline Commie & 4 & 1.3 \\
\hline Bar Attendant & 19 & 6.3 \\
\hline Finance/Account Attendant & 11 & 3.6 \\
\hline Guest Relations Attendant & 8 & 2.6 \\
\hline Human Resources Attendant & 9 & 3.0 \\
\hline Sales and Marketing Attendant & 1 & 0.3 \\
\hline Other & 92 & 30.3 \\
\hline No reply & 20 & 6.6 \\
\hline Total & 304 & 100 \\
\hline
\end{tabular}


As seen also in Table 7, approximately one participant out of two work in waiter position. Other positions represent a small percentage, however; 30,3\% of the participants marked the option 'other' for the relevant question. Majority of employees marking this option stated that they were working in positions such as cook, coordinator, dishwasher, team leader, cashier, banquet manager, bellboy/cloakroom attendant.

In the next stage, how the group constituting the sampling are employed in their business and their daily average working hours were reviewed. The findings are given in Table 8.

Table 8. Employment Forms of Participants and Their Average Working Hours

\begin{tabular}{|l|c|c|}
\hline Your Form of Employment? & Frequency (n) & Percentage (\%) \\
\hline Full time & 171 & 56.3 \\
\hline Part time & 80 & 26.3 \\
\hline No reply & 53 & 17.4 \\
\hline Your Average Daily Working Hours? & Frequency (n) & Percentage (\%) \\
\hline 4-7 hours & 24 & 7.9 \\
\hline 8 hours & 75 & 24.7 \\
\hline 9-11 hours & 90 & 29.6 \\
\hline 12 hours & 58 & 19.1 \\
\hline Above 12 hours & 46 & 15.1 \\
\hline 24 hours & 5 & 1.6 \\
\hline No reply & 6 & 1.9 \\
\hline Total & 304 & 100 \\
\hline
\end{tabular}

As also seen in table 8, more than half of the sampling are employed as full time in the establishments they work. The ones working part-time have a rate of $26,3 \%$. It was determined that $54,3 \%$ of the participants worked $8-11$ hours daily in average. 58 employees stated that they worked 12 hours daily. The rate of employees working over 12 hours is $15,1 \%$. Based on these findings, it can be generally said that the problem regarding long hours of working in tourism is also applicable for food and beverage enterprises in Kyrgyzstan.

In the next stage, job experiences and foreign language levels of the participants were reviewed. The findings are given in Table 9.

Table 9. Job Experiences and Foreign Language Levels of Participants

\begin{tabular}{|l|c|c|}
\hline $\begin{array}{l}\text { How Long Have You Been Working In Food } \\
\text { and Beverage Sector? }\end{array}$ & Frequency (n) & Percentage (\%) \\
\hline 1-5 years & 110 & 36.2 \\
\hline 6-10 years & 119 & 39.1 \\
\hline 11-15 years & 53 & 17.4 \\
\hline 16-20 years & 10 & 3.3 \\
\hline No reply & 12 & 3.9 \\
\hline $\begin{array}{l}\text { Do You Have Job Experience in Other } \\
\text { Tourism Establishments? }\end{array}$ & Frequency (n) & Percentage (\%) \\
\hline $\begin{array}{l}\text { No, I've just worked at food and beverage } \\
\text { establishments }\end{array}$ & 200 & 65.8 \\
\hline I worked at travel agencies & 5 & 1.6 \\
\hline
\end{tabular}




\begin{tabular}{|c|c|c|}
\hline I worked at airplane companies & 3 & 1.0 \\
\hline I worked at hotels & 45 & 14.8 \\
\hline Other & 32 & 10.5 \\
\hline No reply & 19 & 6.2 \\
\hline Total & 304 & 100 \\
\hline Foreign Languages You Speak?' & Frequency (n) & Percentage (\%) \\
\hline English & 87 & 18.2 \\
\hline Russian & 285 & 60.0 \\
\hline German & 12 & 2.5 \\
\hline Turkish & 82 & 17.2 \\
\hline Other & 10 & 2.1 \\
\hline Total & 476 & 100 \\
\hline
\end{tabular}

As also seen in Table 9, it was identified that three out of four participants had a job experience between 1 - 10 years in food and beverage sector. It is again understood from findings in the table that majority of the group $(65,8 \%)$ constituting the sampling do not have a job experience in tourism establishments other than food and beverage enterprises. Despite that, $14,8 \%$ of the participants were detected to have worked also in hotels. Besides, $60 \%$ of the employees stated that they had a knowledge of foreign language. The ones who gave 'English' to the relevant question had a rate of $18,2 \%$ and the ones who gave 'Turkish' had $17,2 \%$. It is considered normal that the most given answer was marked as 'Russian' for the relevant question. Because in Kyrgyzstan, Russian also used as official language together with Kyrgyz. Especially in daily life, majority of young population speak Russian together with Kyrgyz. Moreover, it can be said that the daily life flows with these two languages particularly in the capital Bishkek. But it is remarkable that a relatively small part of the group constituting the sampling $(18,2 \%)$ have stated that they had a knowledge of English as foreign language. Considering that the number of European tourists visiting Kyrgyzstan in recent years have increased and that these people make consumption at food and beverage enterprises, the number of English speaking participants would be expected higher. Based on such a finding, it is likely to say that the number of employees having English as foreign language are quite limited at food and beverage enterprises in Kazakhstan. Again, that $17,2 \%$ of participants have marked 'Turkish' option as foreign language could be considered an important finding. Particularly, an important population having Turkish Republic citizenship residing in Bishkek could have affected on emergence of such a result. Or as the Turkish dialects are usually quite close to each other, it could have allowed the young people in the country to learn Turkish in a short time and use Turkish at food and beverage enterprises.

Finally in the research; participants' reasons to work in food and beverage sector, their monthly salaries and levels of satisfaction from the profession were reviewed. The findings are given in Table 10.

1 In this question, the participants were allowed to choose more than one option. 
Table 10. Other Findings

\begin{tabular}{|c|c|c|}
\hline Are You Working At Your Dream Job? & Frequency (n) & Percentage (\%) \\
\hline Yes & 167 & 54.9 \\
\hline No & 104 & 34.2 \\
\hline No reply & 33 & 10.9 \\
\hline Total & 304 & 100 \\
\hline Your Reason to Work at Food and Beverage Sector? ${ }^{2}$ & Frequency (n) & Percentage (\%) \\
\hline To make money for a temporary period of time. & 132 & 40.4 \\
\hline As my education background fits with this job. & 80 & 24.5 \\
\hline Recommendation from my family, friends and teachers & 16 & 4.9 \\
\hline As the food and beverage sector has high business advantages & 32 & 9.8 \\
\hline As the owner of this enterprise is my relative/friend & 33 & 10 \\
\hline As I have no other option & 34 & 10.4 \\
\hline Total & 327 & 100 \\
\hline Are you Pleased to Work In Food and Beverage Sector? & Frequency (n) & Percentage (\%) \\
\hline Pleased & 145 & 47.7 \\
\hline Neutral & 101 & 33.2 \\
\hline Not Pleased & 47 & 15.5 \\
\hline No reply & 11 & 3.6 \\
\hline Total & 304 & 100 \\
\hline Are You Pleased With the Job You are Currently Performing? & Frequency (n) & Percentage (\%) \\
\hline Pleased & 129 & 42.4 \\
\hline Neutral & 89 & 29.3 \\
\hline Not Pleased & 73 & 24 \\
\hline No reply & 13 & 4.3 \\
\hline Total & 304 & 100 \\
\hline Your Monthly Wage At the Enterprise You Work in? & Frequency (n) & Percentage (\%) \\
\hline Below 250 dollars & 222 & 73 \\
\hline 251-500 dollars & 47 & 15.5 \\
\hline 501-800 dollars & 9 & 3 \\
\hline Above 1000 dollars & 2 & 0.7 \\
\hline No reply & 24 & 7.9 \\
\hline Total & 304 & 100 \\
\hline Are You Pleased With the Wage You are Earning At the Enterprise You Work in? & Frequency (n) & Percentage (\%) \\
\hline Pleased & 106 & 34.9 \\
\hline Neutral & 65 & 21.4 \\
\hline Not Pleased & 117 & 38.5 \\
\hline No reply & 16 & 5.3 \\
\hline Total & 304 & 100 \\
\hline
\end{tabular}

2 In this question, the participants were allowed to choose more than one option. 


\begin{tabular}{|l|c|c|}
\hline Do You Think to Work In Food and Beverage Sector Also In the Future? & Frequency (n) & Percentage (\%) \\
\hline Yes, I definitely think & 107 & 35.2 \\
\hline I think about working for some time & 61 & 20.1 \\
\hline No, I definitely don't think to work & 63 & 20.7 \\
\hline I haven't decided yet & 60 & 19.7 \\
\hline No reply & 13 & 4.3 \\
\hline Total & 304 & 100 \\
\hline
\end{tabular}

The findings in Table 10 can be summarized as follows: It is observed that more than half of the participants $(54,9 \%)$ work in their 'dream jobs'. However, an interesting contradiction is that $40 \%$ of the sampling see this job as 'an instrument to make money for a temporary period'. The rate of ones who state that they work in food and beverage field as 'it fits to education they have received' is $24,5 \% .9,8 \%$ of the participants perceive business advantages of this sector as high. 10,4\% of the sampling stated that they work in food and beverage sector as 'they don't have any other option'. Nearly half of the participants $(47,7 \%)$ are pleased to work in food and beverage sector. But a section of $33,2 \%$ is in a 'neutral' tendency for that issue. Again $42,4 \%$ of the sampling stated that they were pleased with the 'job they are currently performing'. In this case, the ones who marked the option 'neutral' has a rate of $29,3 \%$. Besides, approximately each three out of four employees (73\%) obtain a wage below 250 usd dollars from the establishments they work in. Nevertheless, $34,9 \%$ of the participants are pleased with their monthly average earnings in the establishments they work. The ones who gave 'not pleased' answer for this question has a rate of $38,5 \%$. Finally, it was determined that $35,2 \%$ of participants definitely think to work in food and beverage sector also in the future. 61 employees gave 'I think about working for some time' answere for the relevant question. The ones who definitely don' $t$ think to work in this field in the future has a rate of $20,7 \% .19,7 \%$ of the sampling has a 'neutral' attitude for this issue.

\section{Conclusion}

As the food and beverage industry which has an important place in economies of both developed and developing countries keeps on growing rapidly, it is witnessed that the competition among the establishments in this industry is gradually increasing. Although there are many factors that determine the success of food and beverage establishments or allow them stay competitive, the importance of having qualified labor force continue to be relevant. In other words, it does not seem possible for food and beverage establishments to succeed today only with their physical qualities. This issue has made labor force a strategical element in food and beverage establishments.

Kyrgyzstan has an important superiority in labor market with its young population. The number of establishments serving the country's economy increases each passing day and this situation brings new employment opportunities for potential employers. In the data of National Statistical Committee of the Kyrgyz Republic 2018, the current number of registered food and beverage establishments in the country is 4120 . Great majority of these establishments are active in the capital Bishkek. In the strategic plans that was put forward by Kyrgyzstan government, they declared tourism sector as one of the sectors to be improved with priority in Kyrgyzstan. This situation gives clues regarding that tourism investments in the country will 
increase in the near future. It is thought that the investments related to food and beverage establishments will also be effected positively from this development.

Based on the relevant assumptions, profiles of the employees working at food and beverage establishments in Kyrgyzstan were attempted to be found in this study. As sample, the employees who are working at food and beverage enterprises active in Bishkek were selected. The most remarkable findings in conclusion of the study can be summarized as follows:

- Mostly female and single employees are working at food and beverage establishments in Kyrgyzstan.

- Majority of the employees are between $17-25$ age range and mostly Kyrgyz citizens.

- Though the employees show a balanced distribution according to educational status, it stands out that high school, vocational school and university graduates are employed more in the sector.

- Job experiences for the majority of employees in food and beverage sector is between 1 10 years. It was determined that great majority of the participants had a job experience only in food and beverage sector. Even at a small rate, a part of the employees stated that they also had job experience at hotels.

- Great majority of the employees indicated that they knew Russian as the foreign language. Even at small rates, a part of the participants stated that they have the knowledge of English and Turkish as foreign language.

- It was detected that more than half of the sample worked $8-11$ hours daily in average and that approximately three out of four of them obtained a wage of 250 dollars per month. Despite that, it was identified that approximately one of two employees were pleased to work in food and beverage sector.

- Most of the employees indicated that they were currently working in the profession they have dreamed of, but also as an interesting contradiction; that they preferred this field to earn money for a temporary period.

- Finally, it was determined that approximately one third of the employees definitely think of working in food and beverage sector also in the future.

\section{Limitations and Suggestions for Further Researches}

This research is limited with the employees working at food and beverage sectors active in the capital of Kyrgyzstan, Bishkek. In the following studies, profiles of employees working at food and beverage establishments in other important tourism destinations of Kyrgyzstan (i.e. Issyk-Kul Lake, Karakol) may be reviewed. Also for the generalization of research results, the research may be conducted on a broader sample mass.

\section{Acknowledgements}

This study was presented at the $9^{\text {rd }}$ International Congress on Entrepreneurship organized by Kyrgyz-Turkish Manas University in Bishkek city of Kyrgyzstan in the date 1o-12 May 2018 and published only in the abstract proceedings book. 


\section{References}

Akçadağ, S., Özdemir, E. 2005. İnsan Kaynakları Kapsamında 4 ve 5 Yıldızlı Otel İşletmelerinde İş Tatmini: İstanbul'da Yapılan Ampirik Bir Çalışma. Kocaeli Üniversitesi Sosyal Bilimler Enstitüsü Dergisi 10(2), 167-193 (in Turkish).

Akın, A., Akın, A. 2015. Yiyecek-İçecek İşletmelerinde Uygulanan Maliyet Kontrol Sistemlerinin Tespitine Yönelik Bir Araştırma: Gaziantep Örneği. Akademik Bakış Dergisi (36), 1-16 (in Turkish).

Akoğlan, M., Kozak, N. 1995. Otel İşletmelerinde Personel Kullanım Alanları Üzerine Bazı Gözlemler. Anatolia: Turizm Araştırmaları Dergisi 6(2), 36-39 (in Turkish).

Aynalem, S., Birhanu, K., Tesefay, S. 2016. Employment Opportunities and Challenges in Tourism and Hospitality Sectors. Journal of Tourism \& Hospitality 5(6), 1-5.

Baker, S., Bradley, P., Huyton, J. 1998. Principles of Hotel Front Office Operations. London: Cassell Educational Limited.

Baum, T. 2015. Human resources in tourism: Still waiting for change? - A 2015 reprise. Tourism Management (50), 204-212.

Baum, T., Kralj, A., Robinson, R., Solnet, D. 2016. Tourism workforce research: A review, taxonomy and agenda. Annals of Tourism Research (6o), 1-22.

Bhutia, D. 2014. The Role of Tourism for Human Resource Development in Darjeeling District of West Bengal, India. Journal of Tourism and Hospitality Management 2(1), 113-128.

Chan, W.L. et al. 2014. The Product-related Failures in Restaurants. Procedia-Social and Behavioral Sciences (144), 223-228.

Crick, A. P., Spencer, A. 2011. Hospitality quality: New directions and new challenges. International Journal of Contemporary Hospitality Management 23(4), 463-478.

Çekal, N. 2013. Yiyecek İçecek İşletmelerinde Mutfak Tasarımında Dikkat Edilmesi Gereken Faktörler. e-Journal of New World Sciences Academy 8(1), 62-66 (in Turkish).

Doğan, S., Demiral, Ö. 2015. İnsan Kaynakları Yönetiminde Çalışanların Kendilerine Doğru Yolculuk Yöntemi: Yetenek Yönetimi. Çukurova Üniversitesi Sosyal Bilimler Enstitüsü Dergisi 17(3), 145-166 (in Turkish).

Doğdubay, M., Karan, İ. 2015. Yiyecek-İçecek İşletmelerinde Etik Uygulamaların SWOT Analizi İle Değerlendirilmesi. Journal of Tourism and Gastronomy Studies 3(4), 4-32 (in Turkish).

Erdem, B. 2003. Otel İşletmelerinde İnsan Kaynakları Yönetiminin Yeri ve Önemi. İş, Güç Endüstri İlişkileri ve İnsan Kaynakları Dergisi 5(2), http://www.isguc.org/?p=article\&id=136\&cilt=5\&sayi=2\&yil=2003 (Retrieved March 09, 2018) (in Turkish).

Erdem, B. 2010. Otel Endüstrisinde Yeni Bir Trend: Dizayn Oteller. Gazi Üniversitesi Ticaret ve Turizm Eğitim Fakültesi Dergisi (1), 115-132 (in Turkish).

Erdem, B. 2016. “Temin, Seçim ve İşe Alma”, İçinde: Muharrem Tuna (Editör). İnsan Kaynakları Yönetimi, Birinci Baskı, Ankara: Detay Yayıncılık, ss. .160-227 (in Turkish).

Erdem, B., Gülcan, B., Tokmak, C., Asanova, K., Margazieva, N. 2015. Kırgızistan Konaklama Sektöründe İnsan Kaynakları Profili Araştırması. Manas Sosyal Araştırmalar Dergisi 4.(3), 69-92 (in Turkish).

Erdem, B., Asanova, K., Muradali Uluu, M., Ulan Uluu, D. 2016. The Profile of Human Resources in Hotel Establishments: A Research in Issyk-Kul and Osh Regions of Kyrgyzstan. Keu Vestnik. Musa Ryskulbekov Kyrgyz Economic University 3(37), 257-262.

Erdem, B., Gezen, T. 2014. Turizm İşletmelerine Yönelik İş İlanlarının İçerik Analizi Yöntemiyle İncelenmesi. Uluslararası Yönetim, İktisat ve İşletme Dergisi 10(21): 19-42 (in Turkish). 
Erdem, B. 2019. Konaklama Isşletmeleri Kat Hizmetleri Bölümünde İşgücü Analizi (İşgörenlerin Profili, Mesleğin Sosyal Statüsü ve Mesleğe Bağlllık Ekseninde Türkiye ve Kirglzistan'da Karşılaştırmalı Görgül Bir Araştırma). Ankara: Detay Yayıncılık (in Turkish).

Friddle, C. G., Mangaraj, S., Kinsey, J. D. 2001. The Food Service Industry: Trends and Changing Structure in the New Millennium. Working Paper 01-02, The Retail Food Industry Center, University of Minnesota, St. Paul, MN, March.

Gani, S. A., Dar, M. A. 2018. Human Resources in Tourism Industry: The Real Game Changers. IOSR Journal of Business and Management 20(3), 83-90.

Gruescu, R. Nanu, R., Pirvu, G. 2008. Human Resource Management in the Tourism Industry. Bulletin UASVM, Horticulture 65(2), 168-173.

Güler, S. 2007. Yiyecek ve İçecek İşletmeleri İçin Rekabet Avantajı Yaratacak Stratejik Seçenekler. Anatolia: Turizm Araştırmaları Dergisi 18(1), 101-104 (in Turkish).

Hady, S. A., Chible, H. 2018. The Impact of Human Resource Management Practices on Turnover "Case Study Travel Agencies in Beirut Lebanon". Journal of Tourism and Hospitality Management 6(2), 56-71.

Herman, S. 2015. Management of Human Resources in Tourism. Interdisciplinary Management Research (11), 180-188.

İçöz, O. 1991. Turizm Sektörünün Gelişmesinde İnsan Unsurunun Önemi. Anatolia: Turizm Araştırmaları Dergisi (23-24), 15-18 (in Turkish).

Kılıç, B., Eleren, A. 2009. Turizm Sektöründe Hizmet Kalitesi Ölçümü Üzerine Bir Literatür Araştırması. Alanya İşletme Fakültesi Dergisi 1(1), 91-118 (in Turkish).

Koşan, L. 2013. Menü Analizinde Geleneksel ve Çağdaş Yöntemlerin Karşılaştırılması. Niğde Üniversitesi İIBF Dergisi 6(1), 203-219 (in Turkish).

Kusluvan, S., Kusluvan, Z., Ilhan, I., Buyruk, L. 2010. The human dimension: A review of human resource management issues in the tourism and hospitality industry. Cornell Hospitality Quarterly 51(2), 171-214.

Milić, V. J., Jovanović, S., Krstić, B. 2011. Human Resources İn Tourİsm as a Factor of Its Employment and Competitiveness Growth - Comparative Analysis of Serbia and Surrounding Countries. Facta Universitatis Series: Economics and Organization 8(4), 433-445.

Mullins, L. J. 1995. Hospitality Management a Human Resources Approach. Second Edition, London: Pitman Publishing, England.

Nickson, D. 2007. Human Resource Management for the Hospitality and Tourism Industries. Butterworth-Heinemann, Elsevier Ltd.

Olcay, A., Özekici, Y. K. 2015. Yiyecek-İçecek İşletmelerinde Hizmet Hataları, Telafi Yöntemleri ve Müşteri Memnuniyeti İlişkisi (Gaziantep Örneği). Uluslararası Sosyal Araştırmalar Dergisi 8(41), 1254-1268 (in Turkish).

Pfitzer M., Krishnaswamy, R. 2007. The Role of Food \& Beverage Sector in Expanding Economic Opportunity. Corporate Social Reponsibility Initiative Report No. 20, Kennedy School of Government, Harvard University, Cambridge, MA. http://www.fao.org/fileadmin/user upload/ivc/docs/UnileverandProjectNovella.pdf (Retrieved May 25, 2019)

Prayag, G., Hosany, S. 2015. Human resource development in the hotel industry of Mauritius: myth or reality?. Current Issues in Tourism 18(3), 249-266.

Sabuncuoğlu, Z. 20oo. İnsan Kaynakları Yönetimi. Bursa: Ezgi Kitabevi (in Turkish).

Saldamlı, A. 200o. Otel İşletmelerinde Stres Kaynakları ve Çalışanlar Üzerindeki Etkileri: Beş Yıldızlı Otellerde Bir Uygulama. Çukurova Üniversitesi Sosyal Bilimler Enstitüsü Dergisi 6(6), 288-302 (in Turkish). 
Swain, S. K., George, P. 2007. HRD practices in the classified hotels in Orissa: a study of employee perceptions. PASOS. Revista de Turismo y Patrimonio Cultural 5(1), 81-97.

Usal, A., Kurgun, O. A. 2006. Turizm Isşletmelerinde Maliyet Analizi. Ankara: Detay Yayıncılık (in Turkish).

Yelboğa, A. 2008. Örgütlerde Personel Seçimi ve Psikolojik Testler. Sosyal Bilimler Dergisi 5(2), 11-26 (in Turkish).

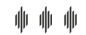

Internet 1: http://teftis.kulturturizm.gov.tr/TR,14518/turizm-tesislerinin-belgelendirilmesine-ve-niteliklerin-.html (04.04.2018)

Internet 2: https://repository.nwu.ac.za/bitstream/handle/10394/9541/Viljoen_AH_Chapter_2.pdf?sequence $=3$ \&isAllowed $=y(25.05 .2019)$

Internet 3: http://www.stat.kg/media/publicationarchive/3a116eea-4813-431a-91eo-ba9c6 5e13231.pdf (25.05.2019)

Internet 4: http://www.stat.kg/media/publicationarchive/fbc43386-73f6-4a39-b615-c8o68db349f8.pdf (25.05.2019) 